\title{
EFFECT OF DIFFERENT LEVELS AND TIMING OF BORON FOLIAR APPLICATION ON GROWTH, YIELD AND QUALITY OF SUNFLOWER GENOTYPES (Helianthus annuus L.)
}

Ayad T. Shaker

Field Crop Dept.

College of Agric. And Forestry

Education
Saad A. Mohammed

Science Dept.

College of Basic

Univ. of Mosul , Iraq

\begin{abstract}
Two field experiments were conducted at AL-Rashidia Location, west north Mosul city, Nineveh province, during two successive growing of 2008 : spring and autumn, in a sandy Loam soil to study the response growth, yield and quality of four sunflower genotypes to boron levels and timing of foliar application. Each experiment comprised four sunflower genotypes (Euroflor, Record, Coban and ALbena), three levels of boron foliar application (0.3 and $\left.6 \mathrm{mg} . \mathrm{l}^{-1}\right)$, and three timing of boron sprayed on the plant leaves one dose during (6 leaves stage, budding stage and $50 \%$ flowering stage). They were conducted according to randomized completely block design with split - split plot with three replications. Results showed that the genotype Euroflor gave a high mean values of leaf area , head diameter , number of seeds / head , 1000 seed weight, seed yield and oil yield, while Albena genotype gave a high value of seed oil percentage for both seasons spring and autumn respectively. Boron sprayed on the plant leaves with concentration $3 \mathrm{mg} . \mathrm{l}^{-1}$ led significant increase in leaf area, head diameter, number of seeds/ head , 1000 seed weight , seed yield and oil yield, while increasing concentration of boron to $6 \mathrm{mg}^{-1}$ increased seed protein percentage and protein yield. Delaying timing of boron foliar application to budding stage achieved highest values for most characters. Interaction genotypes $\mathrm{x}$ boron levels gave significant increase in leaf area , head diameter, number of seeds / head , 1000 seed weight and seed yield. Similar result were obtained from the interaction between boron levels $\mathrm{x}$ timing of boron application, further more, the same trend was recorded for seed oil percentage parameter. Moreover, genotypes $\mathrm{x}$ time of boron application, genotypes $\mathrm{x}$ boron levels $\mathrm{x}$ time of boron application had a significant affect on some characters under study.
\end{abstract}

\section{INTRODUCTION}

The importance of boron deficiency for sunflower has been reported by Blamey (1976), and Chatterjee and Nautiyal (2000). Boron fertilization of sunflower on soil with a ph 4.9 resulted increased yield and seed oil content for two genotypes (Brown and $\mathrm{Hu}, 1997)$. Concomitant with the increased oil content, protein content for one cultivar was significantly decreased by boron fertilization. The decrease in protein content was not as great as the increase in oil brought about by boron fertilization, presumably indicating a change in the kernel to hull ratio. Even in conditions where seed yield was not affected by boron fertilization, higher levels of boron reduced seed oil content 
(Beauguillaume and Cadeac, 1992) (Bredenhann, 1999). High boron supply after anthesis resulted in lower seed oil and higher protein contents (Meszaros and Simits, 1992), also found a decrease in seed oil content with increasing levels of boron application. Baldini and vannozzi (1996) have found that an increased supply of boron improves hull ability. The aim of the present research was to through some light on the factors which govern the effect of different levels and timing of boron foliar application on growth, yield and quality of sunflower genotypes.

\section{METERALS AND METHODS}

Two field experiments were conducted at AL-Rashidia location $20 \mathrm{~km}$ in the west north Mosul city, Nineveh province, during two successive growing seasons of 2008: spring and autumn, in a sandy loam soil to study the effect of different levels and timing of boron foliar application on growth , yield and quality of sunflower genotypes. Each experiment comprised four sunflower genotypes (Euroflor, Record, Coban and ALbena), with three levels of boron foliar application $\left(0,3\right.$ and $\left.6 \mathrm{mg} . \mathrm{l}^{-1}\right)$, and three timing of boron application (6 leaves stage, budding stage and $50 \%$ flowering stage). The experimental design was split-split plot in a randomized completely block design with arrangement keeping with genotypes as main plots, the sub plots were assigned to boron foliar application, while timing of boron application as sub-sub plots with three replications according to Steel and Torrie (1980). The Duncans multiple range test (Duncan, 1955) was used to compare among means (Anonymous,2001). A representative soil sample (0 to $30 \mathrm{~cm}$ depth) was taken before planting (Table 1) using the methods description by Black (1985), Page et al.(1982) and Tendon (1999) . Boron determined by Jac kson

Table (1): Some physical and chemical characteristics of the experimental site.

\begin{tabular}{|c|c|c|}
\hline Soil analysis & Spring season & Autumn season \\
\hline I-physical analysis: & \multicolumn{2}{|}{} \\
\hline Clay (\%) & 17.0 & 12.0 \\
\hline Silt (\%) & 22.0 & 33.0 \\
\hline Sand (\%) & 61.0 & 55.0 \\
\hline Texture & Sandy loam & Sandy loam \\
\hline II-chemical analysis: & \multicolumn{2}{|}{} \\
\hline Organic matter $(\mathrm{gm} / \mathrm{kg})$ & 13.8 & 11.7 \\
\hline Available N (ppm) & 38.6 & 45.2 \\
\hline Available P $(\mathrm{ppm})$ & 16.4 & 14.8 \\
\hline Available K $(\mathrm{ppm})$ & 182.0 & 176.0 \\
\hline Available B $(\mathrm{ppm})$ & 2.3 & 2.4 \\
\hline CaCo $(\mathrm{gm} / \mathrm{kg})$ & 252.0 & 258.0 \\
\hline $\mathrm{PH}$ & 6.3 & 7.2 \\
\hline $\mathrm{EC}(\mathrm{ds} / \mathrm{cm})$ & 2.0 & 2.2 \\
\hline
\end{tabular}

method (1973). Sowing dates were 3 rd April, June and harvested at $12^{\text {th }}$, August, $1^{\text {st }}$ October for Spring and Autumn growing seasons respectively. Calcium superphosphate $150 \mathrm{~kg} / \mathrm{ha}\left(48 \% \mathrm{P}_{2} \mathrm{O}_{5}\right)$ added during soil preparation. 
Potassium sulphate $60 \mathrm{~kg} / \mathrm{ha}\left(48 \% \mathrm{~K}_{2} \mathrm{O}\right)$ were applied in two equal doses to the soil, first half was added during the sowing period, while second half was added after 45 days after sowing. nitrogen were applied to the soil surface in two equal doses, half with sowing and the remaining half at immediately after one month after sowing at a rate of $100 \mathrm{~kg} / \mathrm{ha}$ as urea $(46 \% \mathrm{~N})$. Boron were sprayed $\left(0,3\right.$ and $6 \mathrm{mg}$. $\left.\mathrm{l}^{-1}\right)$ on the leaves, ever dose applied during 6 leaves stage, budding stage and $50 \%$ flowering stage as boric acid $\left(\mathrm{H}_{3} \mathrm{BO}_{3} 17 \% \mathrm{~B}\right)$. Each plot $22.5 \mathrm{~m}^{2}$ included sex ridges with $75 \mathrm{~cm}$ apart to attain a plant density of $44.444 \mathrm{plant} / \mathrm{ha}$. The first irrigation was applied immediately after sowing and after wards irrigation was scheduled at about four days intervals. Agricultural practices were applied as recommend for the region. The study was include:

A- Growth characters: leaf area $\left(\mathrm{cm}^{2} /\right.$ plant $)$ and head diameter $(\mathrm{cm})$. was measured by taken ten plant from each treatment.

B- Yield, yield components and quality: number of seed/head, 1000 seed weight (gm), seed yield (ton/ha), seed oil (\%) oil yield (ton/ha), seed protein (\%) and protein yield (ton/ha). Oil seed content was determined using Soxhlet method (Anonymous, 1984). Nitrogen estimated by using Microkieldahl method (protein \% $=\mathrm{N} \%$ x6.25) (Agrawal et al, 1980).

\section{RESULTS AND DISCUSSION}

A- Growth characters, yield and yield components: mean values of leaf area, head diameter, number of seeds/head, 1000 seed weight and seed yield as effected by genotypes, boron levels and time of boron application for both seasons are presented in Table (2). Statistical analysis showed significant differences between each of four sunflower genotypes, boron levels and timing of boron foliar application in all the five traits studied.

1- Effect of genotypes: Euroflor genotype gave a high mean values for characters: leaf area, head diameter, number of seeds/head, 1000 seed weight and seed yield as compared to the Record, Coban and Albena genotypes in both season spring and autumn. Moreover, the differences among the four genotypes in the leaf area may be attributed to the general varietals differences in the number of leaves/plant. The superiority of Euroflor genotype in the seed yield production may be attributed to having ahighest area of leaves resulted in on increase photosynthsis activity and this in turn increased the capacity of dry matter accumulation in the different plant parts. In this report, Kene et al. (1992), Herdem (1999), and Nel (2001) reported that Vidoc genotypes had highest seed yield and dry weight per plant than the Miak and Euroflor genotypes.

2- Effect of boron fertilization: application of $3 \mathrm{mg} \mathrm{l}^{-1}$ of boron fertilizer significantly led to an increase in the following parameters: leaf area, head diameter, number of seeds/head, 1000 seed weight and seed yield by $3.39,4.88$ , $9.39,16.15$ and $8.65 \%$ for spring season, and $2.38,5.21,8.67,16.67$, and $8.46 \%$ for autumn season respectively as compared with check treatment $(0$ mg. $\mathrm{B} \mathrm{l}^{-1}$ ). The stimulatory effect of boron on sunflower plant may be due to its role in enhancing metabolic process and improving development of pollen tube. 
These results are in harmony with those obtained by Harries and Jhon (1996), Sharma et al. (1999), and Connor et al. (2000). Increasing boron levels from 3 to $6 \mathrm{mg} . \mathrm{l}^{-1}$ caused decrease in the previous traits for both seasons. The lack of consistency in the reaction of the seed yield and all related characters to boron fertilization may be due to the difference in soil fertility between the two seasons (Table 1), and the fact that soil moisture status, temperature and even light intensity affect the uptake of boron (Moraghan and Mascagni, 1991). (Table 1) also indicated that the available boron in the soil is in the average of medium level which its ranged from 2.3-2.4 ppm, and this result are in a greement with the classification of Maas (1990). Although sunflower required a high quantity of boron, this reflected the response of the crop to this element when increasing the concentration from 0 to $3 \mathrm{mg} \mathrm{l}^{-1}$. the result from the same table revealed that there was a slight increase in the salinity which caused a shortage of boron availability and this deficit show the need to the compensation applied of the boron. Generally, the maximum seed yield (ton ha ${ }^{1}$ ) were obtained with adding boron fertilizer at the level $3 \mathrm{mg} \cdot \mathrm{l}^{-1}$. The increases in seed yield due to increasing number of seeds / head and 1000 seed weight. Similar results were obtained by Mohammed Ateeque et al (2001), Asad et al (2002) and El-Sadek et al (2004).

3- Effect timing of boron foliar application: spraying boron fertilizer on the leaves at budding stage significantly increased leaf area, head diameter, number of seeds/head, 1000 seed weight and seed yield by $12.80,13.2710 .20,15.22$, and $21.71 \%$ for spring season , and $15.52,9.71,9.93,12.94$ and $21.43 \%$ for autumn season respectively as compared with applying boron fertilizer at $50 \%$ flowering stage. The increase in 1000 seed weight at budding stage may be due to increase in dry matter accumulated in seeds. While delaying timing of boron foliar application reduced yield component characters i.e. head diameter, number of seeds/head and 1000 seed weight at $50 \%$ flowering stage. Similar results were found by Meszaros and Simits (1992) and Baldini and Vannozzi (1996).

4- Interaction effect: the interaction genotypes $\mathrm{x}$ boron levels, boron levels $\mathrm{x}$ timing application of boron showed significant effect on leaf area, head diameter, number of seed/head , 1000 seed weight and seed yield for both seasons as illustrated in Table (2). While the interaction genotypes x timing application of boron showed a significant effect on leaf area for autumn season, number of seeds/head and seed yield for spring and autumn seasons, with this regard, Connor et al (2000), Asad et al (2002) and El-Sadek et al (2004) found that delaying timing of boron foliar application to budding stage increased number of seeds/head, 1000 seed weight and seed yield. The interaction between the three studied factors genotypes $\mathrm{x}$ boron levels $\mathrm{x}$ timing of boron foliar application showed significant effects on head diameter for both growing seasons, number of seeds/head , 1000 seed weight and seed yield in only spring season.

B- Yield and quality: mean values of seed oil, oil yield, seed protein and protein yield as effected by genotypes, boron levels and time of boron application for both season are presented in Table (3). Analysis of variance 
showed significant differences between each of the four genotypes boron levels and timing of boron foliar application in all the four traits studied.

1- Effect of genotypes: the data revealed that Albena genotype surpassed Euroflor, record and Coban genotypes in seed oil percentage in both seasons spring and autumn. However, these differences may be attributed to genetic factors and their interaction with the prevailing environmental conditions. Euroflor genotype surpassed significantly Record, Coban and Albena genotypes in oil yield, seed protein and protein yield in both seasons. The increase in oil and protein yield of Euroflor genotype may be due to their high seed yield per hectare (table 2) rather than differences in seed oil and protein content. The superiority of Euroflor 
Table (2): Mean values of leaf area, head diameter, number of seeds / head, 1000 seed weight and seed yield as affected by boron fertilizer levels and timing application for the sunflower genotypes in spring and autumn season.

\begin{tabular}{|c|c|c|c|c|c|c|c|c|c|c|}
\hline \multirow{2}{*}{ Main effect and interactions } & \multicolumn{2}{|c|}{ Leaf area $\left(\mathrm{cm}^{2} /\right.$ plant $)$} & \multicolumn{2}{|c|}{ Head diameter (cm) } & \multicolumn{2}{|c|}{ No of seeds/head } & \multicolumn{2}{|c|}{1000 seed weight $(\mathrm{gm})$} & \multicolumn{2}{|c|}{ Seed yield (ton/ha) } \\
\hline & Spring season & Autumn season & Spring season & Autumn season & Spring season & Autumn season & Spring season & Autumn season & Spring season & Autumn season \\
\hline \multicolumn{11}{|l|}{ Genotypes (G) } \\
\hline G1:Euroflor & 4393.7 a & 4496.2 a & $22.0 \mathrm{a}$ & 22.6 a & 1148.3 a & 1171.9 a & $76.6 \mathrm{a}$ & 78.1 a & $3.28 \mathrm{a}$ & $3.22 \mathrm{a}$ \\
\hline G2:Record & $3382.0 \mathrm{~b}$ & $3557.1 \mathrm{~b}$ & $21.0 \mathrm{~b}$ & $21.4 \mathrm{~b}$ & $995.4 \mathrm{c}$ & $1015.5 \mathrm{c}$ & $72.2 \mathrm{~b}$ & $74.9 \mathrm{~b}$ & $2.68 \mathrm{c}$ & $2.60 \mathrm{c}$ \\
\hline G3:Coban & $3031.0 \mathrm{c}$ & $3116.2 \mathrm{c}$ & $21.0 \mathrm{~b}$ & $21.5 \mathrm{~b}$ & $1051.9 \mathrm{~b}$ & $1078.7 \mathrm{~b}$ & $69.5 \mathrm{c}$ & $70.6 \mathrm{c}$ & $2.35 \mathrm{~d}$ & $2.26 \mathrm{~d}$ \\
\hline G4:Albena & $2993.0 \mathrm{~d}$ & $2980.3 \mathrm{~d}$ & $20.1 \mathrm{c}$ & $21.0 \mathrm{~b}$ & $966.6 \mathrm{~d}$ & $980.5 \mathrm{~d}$ & $62.1 \mathrm{~d}$ & $63.4 \mathrm{~d}$ & $2.88 \mathrm{~b}$ & $2.83 \mathrm{~b}$ \\
\hline \multicolumn{11}{|l|}{ Boron levels (B) } \\
\hline 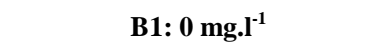 & $3385.1 \mathrm{c}$ & $3496.9 \mathrm{c}$ & $20.5 \mathrm{c}$ & $21.1 \mathrm{~b}$ & $991.2 \mathrm{c}$ & $1015.1 \mathrm{c}$ & $65.0 \mathrm{c}$ & $66.0 \mathrm{c}$ & $2.66 \mathrm{c}$ & $2.60 \mathrm{c}$ \\
\hline B2: $3 \mathrm{mg.l}^{-1}$ & 3500.0 a & $3580.3 \mathrm{a}$ & 21.5 a & 22.2 a & $1084.3 \mathrm{a}$ & 1103.1 a & $75.5 \mathrm{a}$ & $77.0 \mathrm{a}$ & $2.89 \mathrm{a}$ & 2.82 a \\
\hline B3: 6 mg..$^{-1}$ & $3464.8 \mathrm{~b}$ & $3535.0 \mathrm{~b}$ & $21.1 \mathrm{~b}$ & $21.6 \mathrm{~b}$ & $1046.2 \mathrm{~b}$ & $1066.8 \mathrm{~b}$ & $69.8 \mathrm{~b}$ & $72.2 \mathrm{~b}$ & $2.84 \mathrm{~b}$ & $2.77 \mathrm{~b}$ \\
\hline \multicolumn{11}{|l|}{ Timing application of boron $(T)$} \\
\hline T1: 6 leaves stage & $3390.1 \mathrm{~b}$ & $3453.0 \mathrm{~b}$ & $21.3 \mathrm{~b}$ & $21.7 \mathrm{~b}$ & $1046.5 \mathrm{~b}$ & $1063.8 \mathrm{~b}$ & $68.9 \mathrm{~b}$ & $70.4 \mathrm{~b}$ & $2.67 \mathrm{~b}$ & $2.61 \mathrm{~b}$ \\
\hline T2: budding stage & 3689.2 a & 3837.5 a & $22.2 \mathrm{a}$ & $22.6 \mathrm{a}$ & 1087.9 a & 1110.7 a & $75.7 \mathbf{a}$ & $76.8 \mathrm{a}$ & 3.14 a & $3.06 \mathrm{a}$ \\
\hline T3:50\%flowering stage & $2370.6 \mathrm{c}$ & $3321.9 \mathrm{c}$ & $19.6 \mathrm{c}$ & $20.6 \mathrm{c}$ & $987.2 \mathrm{c}$ & $1010.4 \mathrm{c}$ & $65.7 \mathrm{c}$ & $68.0 \mathrm{c}$ & $2.58 \mathrm{c}$ & $2.52 \mathrm{c}$ \\
\hline \multicolumn{11}{|l|}{ Interactions: } \\
\hline $\mathbf{G} \times \mathbf{B}$ & $*$ & $*$ & $*$ & $*$ & $*$ & $*$ & $*$ & $*$ & $*$ & $*$ \\
\hline $\mathbf{G} \mathbf{X} \mathbf{T}$ & n.s. & $*$ & n.s. & n.s. & $*$ & $*$ & n.s. & n.s. & $*$ & $*$ \\
\hline B X T & $*$ & $*$ & $*$ & $*$ & $*$ & $*$ & $*$ & $*$ & $*$ & $*$ \\
\hline G X B XT & n.s. & n.s. & * & $*$ & $*$ & $*$ & $*$ & $*$ & $*$ & n.s. \\
\hline
\end{tabular}

* The means values within column followed by the different letters are significant at $5 \%$ level. 
Table (3): Mean values of seed oil, Oil yield, seed protein and protein yield as affected by boron fertilizer levels and timing application for the sunflower genotypes in spring and autumn season.

\begin{tabular}{|c|c|c|c|c|c|c|c|c|}
\hline \multirow{2}{*}{ Main effect and interactions } & \multicolumn{2}{|c|}{ Seed oil $(\%)$} & \multicolumn{2}{|c|}{ Oil yield (ton/ha) } & \multicolumn{2}{|c|}{ Seed protein $(\%)$} & \multicolumn{2}{|c|}{ Protein yield (ton/ha) } \\
\hline & Spring season & Autumn season & Spring season & Autumn season & Spring season & Autumn season & Spring season & Autumn season \\
\hline \multicolumn{9}{|l|}{ Genotypes (G) } \\
\hline G1:Euroflor & $43.1 \mathrm{~d}$ & $42.6 \mathrm{~d}$ & $1.41 \mathrm{a}$ & $1.37 \mathrm{a}$ & $16.5 \mathrm{a}$ & $17.0 \mathrm{a}$ & $0.54 \mathrm{a}$ & $0.55 \mathrm{a}$ \\
\hline G2: Record & $44.1 \mathrm{c}$ & $43.6 \mathrm{c}$ & $1.18 \mathrm{c}$ & $1.13 \mathrm{c}$ & $15.3 \mathrm{~b}$ & $15.6 \mathrm{~b}$ & $0.41 \mathrm{~b}$ & $0.41 \mathrm{~b}$ \\
\hline G3:Coban & $45.3 \mathrm{~b}$ & $44.8 \mathrm{~b}$ & $1.07 \mathrm{~d}$ & $1.01 \mathrm{~d}$ & $14.2 \mathrm{c}$ & $14.4 \mathrm{c}$ & $0.33 \mathrm{~d}$ & $0.33 \mathrm{~d}$ \\
\hline G4:Albena & 45.7 a & $45.0 \mathrm{a}$ & $1.32 \mathrm{~b}$ & $1.27 \mathrm{~b}$ & $13.6 \mathrm{~d}$ & $13.7 \mathrm{~d}$ & $0.39 \mathrm{c}$ & $0.39 \mathrm{c}$ \\
\hline \multicolumn{9}{|l|}{ Boron levels (B) } \\
\hline B1: 0 mg.l ${ }^{-1}$ & $45.5 \mathrm{a}$ & $45.0 \mathrm{a}$ & $1.21 \mathrm{c}$ & $1.17 \mathrm{c}$ & $14.2 \mathrm{c}$ & $14.4 \mathrm{c}$ & $0.38 \mathrm{c}$ & $0.38 \mathrm{c}$ \\
\hline 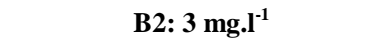 & $44.5 \mathrm{~b}$ & $43.9 \mathrm{~b}$ & $1.29 \mathrm{a}$ & $1.24 \mathrm{a}$ & $15.0 \mathrm{~b}$ & $15.3 \mathrm{~b}$ & $0.43 \mathrm{~b}$ & $0.43 \mathrm{~b}$ \\
\hline 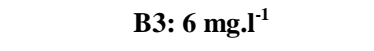 & $43.6 \mathrm{c}$ & $43.2 \mathrm{c}$ & $1.24 \mathrm{~b}$ & $1.20 \mathrm{~b}$ & $15.5 \mathrm{a}$ & $15.8 \mathrm{a}$ & $0.44 \mathrm{a}$ & 0.44 a \\
\hline \multicolumn{9}{|l|}{ Timing application of boron $(T)$ : } \\
\hline T1: 6 leaves stage & $43.9 \mathrm{~b}$ & $43.4 \mathrm{~b}$ & $1.17 \mathrm{~b}$ & $1.13 \mathrm{~b}$ & $15.0 \mathrm{~b}$ & $15.3 \mathrm{~b}$ & $0.40 \mathrm{~b}$ & $0.40 \mathrm{~b}$ \\
\hline T2: budding stage & $46.4 \mathrm{a}$ & 45.7 a & $1.46 \mathrm{a}$ & $1.40 \mathrm{a}$ & $14.1 \mathrm{c}$ & $14.4 \mathrm{c}$ & $0.44 \mathrm{a}$ & 0.44 a \\
\hline T3: 50\%flowering stage & $43.4 \mathrm{c}$ & $43.0 \mathrm{c}$ & $1.12 \mathrm{c}$ & $1.08 \mathrm{c}$ & $15.5 \mathrm{a}$ & 15.9 a & $0.40 \mathrm{~b}$ & $0.40 \mathrm{~b}$ \\
\hline \multicolumn{9}{|l|}{ Interactions: } \\
\hline $\mathbf{G} \times \mathbf{B}$ & n.s. & n.s. & n.s. & n.s. & n.s. & n.s. & n.s. & n.s. \\
\hline $\mathbf{G} \mathbf{X} \mathbf{T}$ & $*$ & n.s. & n.s. & n.s. & n.s. & n.s. & n.s. & n.s. \\
\hline $\mathbf{B} \mathbf{X} \mathbf{T}$ & $*$ & $*$ & n.s. & n.s. & n.s. & n.s. & n.s. & n.s. \\
\hline G X B X T & n.s. & n.s. & n.s. & n.s. & n.s. & n.s. & n.s. & n.s. \\
\hline
\end{tabular}

* The means values within column followed by the different letters are significant at $5 \%$ level. 
genotype in the most seed characters may be due to had a better vegetative growth and hence photosynthetic process which led to more carbohydrates was translocated from the source (leaves) to the sink (seeds) (Mengel and Kirkby, 1982). Similar conclusion were reported by Villalobos et al. (1994), Ortegon and Diaz (1997) and Ozer (2003).

2- Effect of boron fertilization: seed oil percentage significantly decreased with the increasing boron levels from 0 to $6 \mathrm{mg} \mathrm{l}^{-1}$. However, the decrease in seed oil contents may be due to the increase in seed protein contents at the expense of oil concentration at the same treatment. These results are in agreement with those obtained by Rani and Reddy (1993), Bredenhann (1999). The highest significant values of oil yield obtained with adding boron at the concentration $3 \mathrm{mg} \mathrm{l}^{-1}$. The increment was 6.61 and $5.98 \%$ as compared with control $\left(0 \mathrm{mg}\right.$ boron $\left.^{-1}\right)$ for both seasons spring and autumns respectively. The maximum values of seed protein percentage and protein yield ha ${ }^{-1}$ were obtained with boron fertilizer level $6 \mathrm{mg} \mathrm{l}^{-1}$ and the lowest with control for both seasons.

3- Effect timing of boron foliar application: the application of boron at budding stage led to an increase in seed oil percentage and oil yield by 6.91 and $30.36 \%$ for spring season, and 6.28 and $29.63 \%$ for autumn season respectively compared with boron applied at $50 \%$ flowering stage. These results could be explained according to favorable time of boron foliar application and its effect by increasing leaf area and enhancing photosynthesis activity which, in turn, resulted in an increase in seed and oil yield. These results are in harmony with those obtained by Connor et al. (2000), Mohammed Ateeque et al. (2001), Asad et al. (2002) and El-Sadek et al. (2004). Applying boron at budding stage caused a significant decrease in seed protein percentage by 9.03 and $9.43 \%$ as compared with boron applied at $50 \%$ flowering stage for both seasons. On the contrary highest values of protein yield was obtained at budding stage. This is due to the increase in seed yield.

4- Interaction effect: the Interaction effect genotypes $\mathrm{x}$ boron levels, and genotypes $\mathrm{x}$ boron levels $\mathrm{x}$ timing of boron application for all investigated traits were non significant for both season. This showed that each factor acted independently on these traits. While interactions genotypes $\mathrm{x}$ timing of boron application showed significant effect on seed oil percentage for spring season only. On the other hand, Interaction boron level x timing of boron application had a significant effect on seed oil percentage for both seasons.

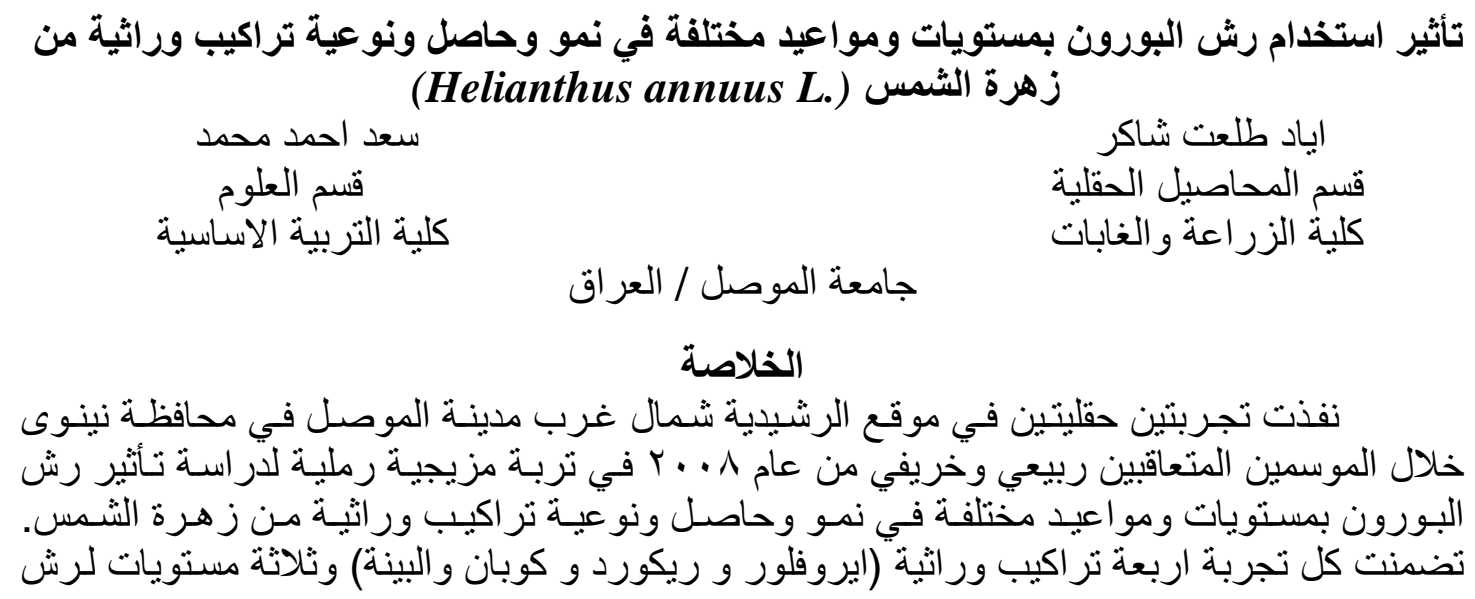




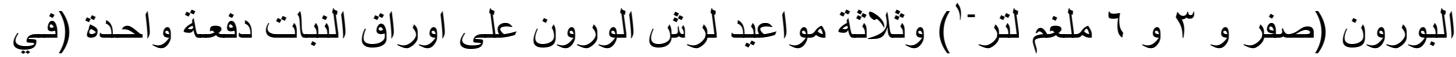

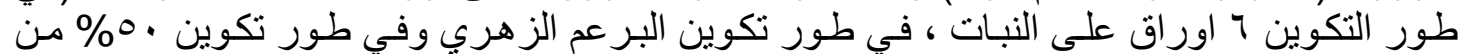

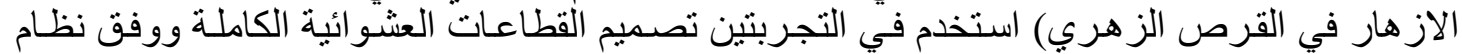

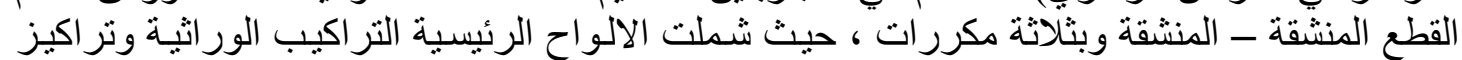

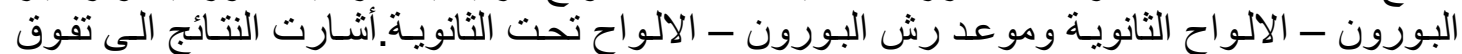

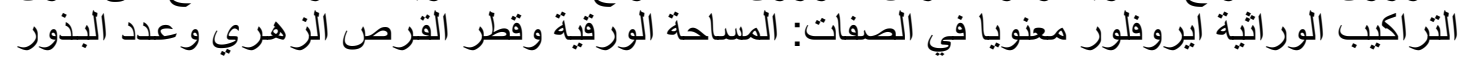

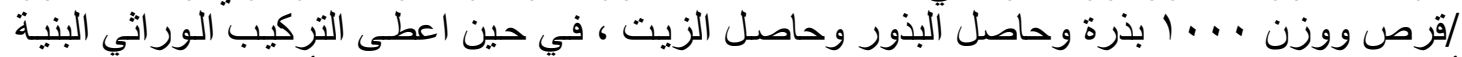

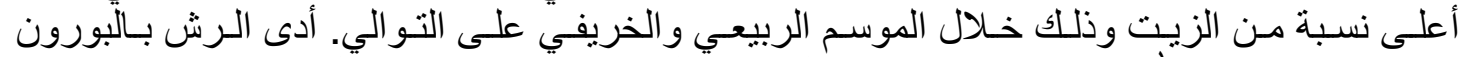

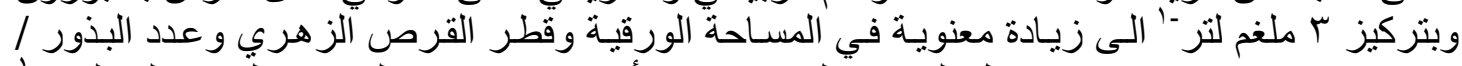

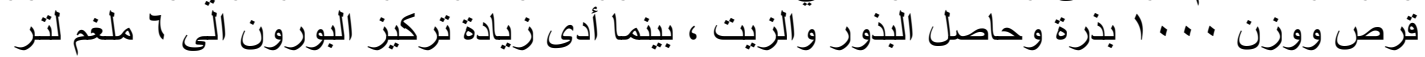

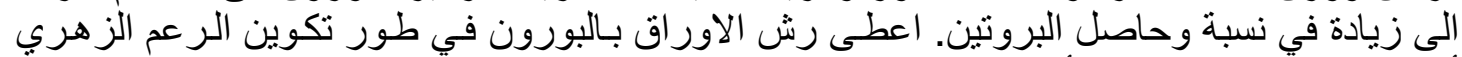

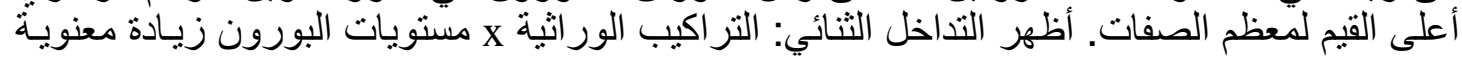

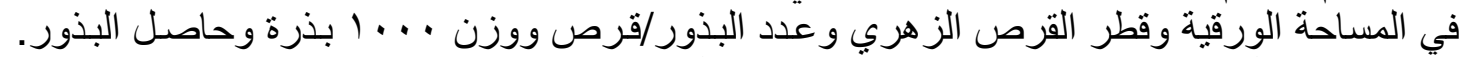

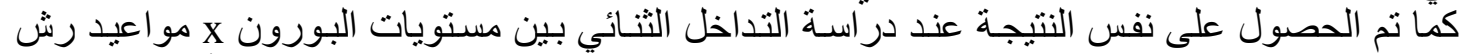

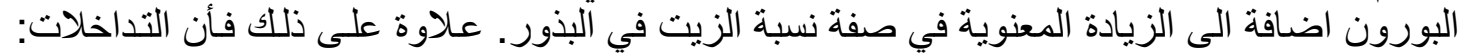

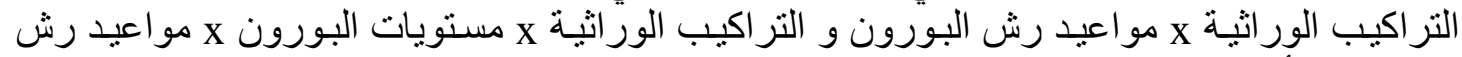
البورون قد أثرت معنوياً في بعض اعيذ الصفات البورن المدروسة.

\section{REFERENCES}

Agrawal , S.C. ; M.S. , Jolly ; A.M. , Sinha (1980). Foliar constituents of secondary food plants of tasar silk Antheraea mylitta. Indian Forester, 106(12): 847-851.

Anonymous. (1984). Official Methods of Analysis. 14 ${ }^{\text {th }}$ Edition Association of Official Analytical Chemists Washington, D.C, USA.

Asad , A. ; F.P.C. , Blarney and D.G. , Edward (2002). Effects of boron foliar application on vegetative and reproduction growth of sunflower. Annals of Botany 92: 1 - 6 .

Baldini , M. and G.P., Vannozzi (1996)- Genotype and environmental effects on hullability in sunflower. results of three years of experimentation. P. 275-283. In Proceedings of the 14th International Sunflower Conference, Beijing-Shenyang, China. 12-20 June 1996. International Sunflower Association. Paris, France.

Beauguillaume, A. and Cadeac, F. (1992). Elements of explication of the variability of the hulling ability in sunflower. P. 993-999. In Proceedings of the 13th International Sunflower Conference, Pisa, Italy. 7-11 September 1992. International Sunflower Association. Paris, France.

Black , C.A. (1965). Methods of Soil Analysis. Part 2.Chemical and Microbiological Properties. Amer. Soc. of Agronomy. Inc. Publisher Madison. USA.

Blamey, F.P.C. (1976).Boron nutrition of sunflowers (Helianthus annuus L.) on an avalon medium sandy loam. Agrochemophysica 8(1): 5-10.

Bredenhann , E. (1999). Sunflower seeds role in the value chain: animal feed perspective. In minutes of the seed quality meeting held on Friday, 20 August 1999 at Continental Oil Mills (pty) Limited. S.A. Sunflower Forum.

Brown, P.H. and H., Hu (1997). Does boron play only a structural role in the growing tissues of higher plants. Plant Soil, 196, 211-215.

Chatterjee, C. and N., Nautiyal ( 2000).Developmental aberrations in seed of boron deficient sunflower and recovery. Journal Plant Nutr. 23, 835-841. 
Connor, D.J.; A.J., Hall and V.O., Sadras (2000). Physiology of yield expression in sunflower (Helianthus annuus L.). Field Crops Research 30(2): 333-389.

Duncan , B.O. (1955). Multiple range and multiple F test. Biometrics 11 : 1-42.

EL-Sadek , A.N.A. ; M.A. , Ashoub ; A.M. , Aboshetaia and M.T. , Hegab (2004). Response of sunflower yield and its atritubes to sowing dates, boron foliar application and nitrogen fertilization under EL-Wadi ELGadeed conditions. Zagazig Journal Agric. Res. 31 (4A): 1257-1277.

Harris , H.C. and B.B. , John (1996). Comparison of Ca and boron deficiencies of plant. I physiological and yield deficiencies. Agron. Journal 58(1): 575-578.

Herdem , (1999). Effect of nitrogen levels on yield and yield components of some sunflower genotypes. M.Sc. Thesis.Field Crops Dept, Agriculture Faculty, Trakya Univ., Tekirdag, Turkey.

Jackson, M.L. (1973). Soil Chemical Analysis. Prentice Hall of India Pvt., New Delhi.

Kene, H.K., V.R. Thosar and R.B. Ulemale (1992). Optimum sowing time of sunflower varieties in summer season. Journal Maharashtra Agri. Univ., 17: 411-415.

Maas , E.V. (1990). Boron Tolerance Limits For Agriculture Crops. United States. Salinity Laboratory

Mengel , K. and E.A. , Kirkby (1982). Principles of plant nutrition . $3^{\text {rd }}$ Ed. Int. Institute Bern, Switzerland.

Meszaros, G. and K. Simits (1992)-Effect of leaf nutrition at different stages of development on achene and oil yield of sunflower. Helia 15, 9-16.

Mohammed Ateeque , G.U. ; Malewar and S.D. , More (2001).Influence of phosphorus and boron on yield and chemical composition of Sunflower. Indian Journal Soc. of Soil Sci. 41 (1) : 100 - 102 .

Moraghan, J.T. and H.J., Mascagni (1991) .Environmental and soil factors affecting micronutrient deficiencies and toxicities. P.371-426. In Journal Mortvedt (Ed) Micronutrients In Agriculture. Number 4 In The Soil Science Society of America Book Series. Sssa, Madison, Wisconsin, Usa.

Nel , A.A. (2001). Determinations of sunflower seed quality for processing . Ph.D. Thesis, Faculty of Natural and Agric. Sci. Univ. of Pretoria , Pretoria .

Ortegon , M.A.S. and F.A., Diaz (1997). Productivity of sunflower cultivars (Helianthus annuus L.) in relation to plant density and growing season in Northern Tamaulipas, Mexico. Helia 20, 113-120.

Ozer, H. (2003) .Sowing date and nitrogen rate effects on growth, yield and yield components of two sunflower Genotypes (Helianthus annuus L.). Europe. Journal Agron., 19: 453-463.

Page , A.L. ; R.H. , Miller and D.R. , Kenney (1 982). Methods of Soil Analysis . Part (2) Agronomy No. 9 Madison. USA .

Rani , P.L. and T.M.M. , Reddy (1993). Effect of nitrogen and boron on yield components, yield and oil content sunflower (Helianthus annuus L.). Journal of Res. APAU . 21 (1/2) 39 - 41.

Anonymous (2001). Statistical Analysis Systems . SAS Institute Inc., Cary, NC, USA.

Sharma , K.R. ; P.C. Srivastara ; D. Ghosh and M.S. Gangwar (1999). Effect of boron and farmyard manure application on growth, yield and boron nutrition of sunflower. Journal Plant Nut. 22 (4 and 5): 633-640. 
Steel , R.G.D. and J.H. , Torrie (1980). Principles and Procedures of Statistics . MC Graw-Hill, New York .

Tandon, H. (1999). Methods of Analysis of Soil, Plants, Water and Fertilizers. Fertilizer Development and Consultation Organization, New Delhi, India , pp : 144.

Villalobos , F.J. ; Sadras, V.O. Soriano ; A. and E. Fereres (1994). Planting density effects on dry matter partitioning and productivity of sunflower hybrids. Field Crops Research 36 (1): 1-11. 